\title{
57. BIOSTRATIGRAPHIC, PALEOENVIRONMENTAL, AND PALEOMAGNETIC SYNTHESIS OF THE GOBAN SPUR REGION, DEEP SEA DRILLING PROJECT LEG 80 ${ }^{1}$
}

\author{
Scott W. Snyder, Department of Geology, East Carolina University \\ Carla Müller, Geologisch-Paläontologisches Institut der Universität Frankfurt am Main \\ Jacques Sigal, Vincennes \\ Hilary Townsend, Department of Oceanography, University of Southampton \\ and \\ C. Wylie Poag, U. S. Geological Survey, Woods Hole²
}

\begin{abstract}
A composite stratigraphic section based on the four DSDP-IPOD Leg 80 drill sites provides a nearly complete record of syn-rift and post-rift events in the vicinity of Goban Spur. Syn-rift sediments were deposited in marginal marine to outer shelf environments. Above the "breakup" unconformity (hiatus spanning most of the Aptian), post-rift Albian sediments indicate the development of a deep-water seaway in the Goban Spur region. The latest Campanian/Maestrichtian interval records the initiation of rather uniform, widely distributed marine sedimentation throughout the region. Climatic changes, rather than changes in water depth, became conspicuous during the Tertiary. Widespread, nearly synchronous periods of nondeposition or erosion occurred in the Paleocene, middle Eocene, middle Oligocene, and late Miocene. Differences in the sediment record among sites are due to their varying positions (1) along the margin of the developing Atlantic seaway and (2) within their respective half-graben depositional basins.
\end{abstract}

\section{INTRODUCTION}

During DSDP-IPOD Leg 80, four sites, across Goban Spur and onto the Porcupine Abyssal Plain, were cored. Goban Spur, which lies along the Irish continental margin north of the Bay of Biscay, is a broad, smooth, and relatively shallow topographic feature formed above a basement high that represents a submarine extension of Cornwall. The basement in this area, and below the adjacent Pendragon Escarpment, is broken by a series of listric normal faults into tilted blocks and intervening half-grabens. Thick syn-rift and post-rift sediment sequences fill the axes of these half-grabens, then thin toward their seaward margins.

Sites 548,549 , and 551 lie at or near the seaward edges of three different half-grabens located progressively farther westward along Goban Spur and Pendragon Escarpment. Site 550 is on the Porcupine Abyssal Plain (Fig. 1A). Together, these four sites form a roughly east-west transect across a relatively sediment-starved continental margin ideally suited to investigation of (1) the subsidence histories of both continental basement and oceanic basement near their junction, (2) the characteristics and ages of numerous seismic unconformities, and (3) the depositional environments of both syn-rift and postrift sediments.

Biostratigraphy, which has contributed significantly to the attainment of the major objectives of Leg 80 , is

\footnotetext{
${ }^{1}$ Graciansky, P. C. de, Poag, C. W., et al., Init. Repts. DSDP, 80: Washington (U.S. Govt, Printing Office).

2 Addresses: (Snyder) Dept. of Geology, East Carolina Univ., Greenville, NC, U.S.A.; (Müller) Geologisch-Palãontologisches Institut der Universităt Frankfurt am Main, West Germany; (Sigal) 33, Rue de Montreuil, 94300 Vincennes, France; (Townsend) Dept. of Oceanog. raphy, Univ. of Southampton, Southampton S09 5NH, U.K.; (Poag) U.S. Geological Survey, Woods Hole, MA, U.S.A.
}

summarized in this chapter. The basic biostratigraphic framework for the Cretaceous has been provided by several authors. Müller (this vol.) used the nannofossil zonations of Thierstein $(1973,1976)$, into which has been integrated information from Martini (1976), Čepek and Hay (1969), and Bukry and Bramlette (1970). Magniez and Sigal (this vol.) used the foraminiferal subdivisions of Bettensteadt (1952), Bartenstein (1978), and Sigal (1977). The Cenozoic biostratigraphic framework is also based on the work of several authors. Müller (this vol.) used the "standard nannofossil zonation" of Martini (1971); and Snyder and Waters (this vol.) used the planktonic foraminiferal zonal schemes of Blow (1969) and Berggren and Van Couvering (1974), into which has been integrated information from Stainforth et al. (1975) and Poore (1979). Detailed discussions of biostratigraphic interpretations are available in these contributions, so only broader, more generalized findings are summarized here. Paleoenvironmental interpretations have been based on lithological, mineralogical, paleontological, geochemical, and geophysical studies by numerous authors of this volume. Their chapters are cited at appropriate places in the following discussions.

Where possible, paleomagnetic interpretations (Townsend, this vol.) are correlated with biostratigraphic subdivisions. Unfortunately, a conclusive magnetic polarity sequence could not be defined for large portions of the sediment section at several sites. For example, all sediments below the base of the Pleistocene $(27 \mathrm{~m}$ sub-bottom) in Hole 549A are weakly magnetized. Because interpretations must therefore be based solely on NRM, the magnetostratigraphy is tentative. Elsewhere, poor core recovery, condensed sections, and numerous reversals combine to make the magnetostratigraphy ambiguous (e.g., the Miocene section of Hole 550). 


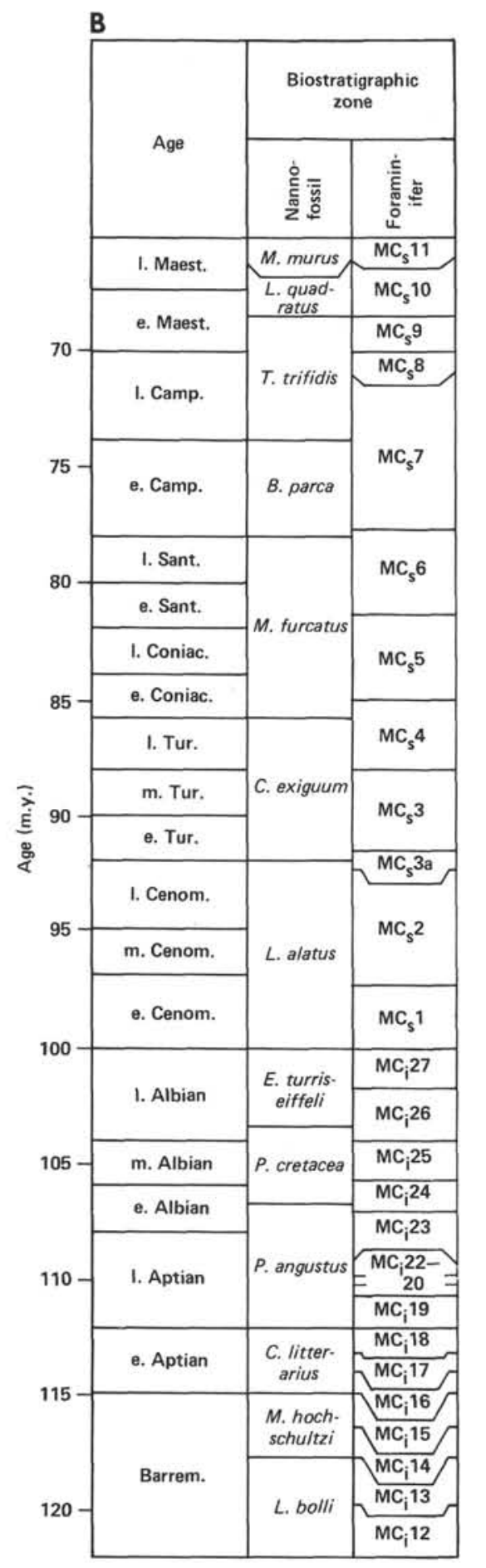

Cretaceous
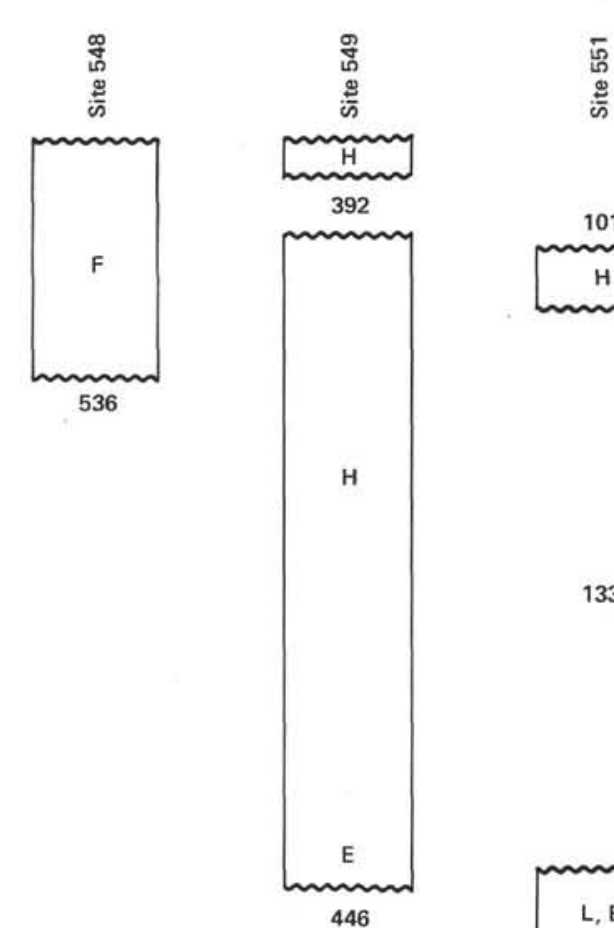

品

कั
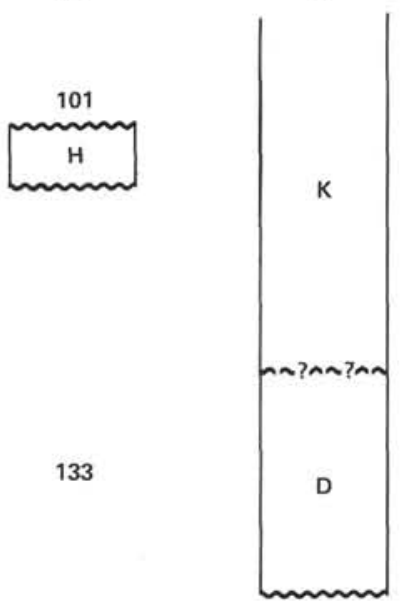

133

595

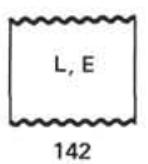

$H$

42

479

c

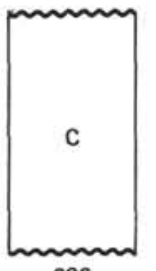

686

B

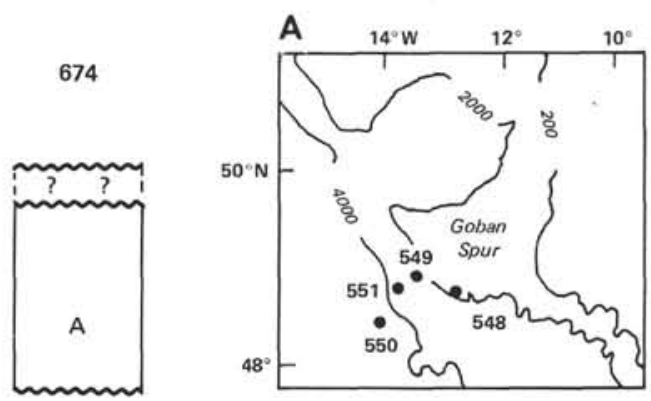

965

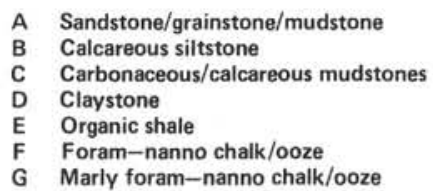

H Nanno chalk/ooze

I Marly nanno chalk/ooze

J Calcareous ooze/mudstone

K Nanno chalk and

interbedded turbidites

L Siliceous chalk and mudstone

Figure 1. A. Locality map. (Water depth in meters.) B. Unconformities identified at Leg 80 sites (depths at which the unconformities occur given in m sub-bottom). Biostratigraphic correlations and absolute age estimates are after Hailwood et al., 1979. 


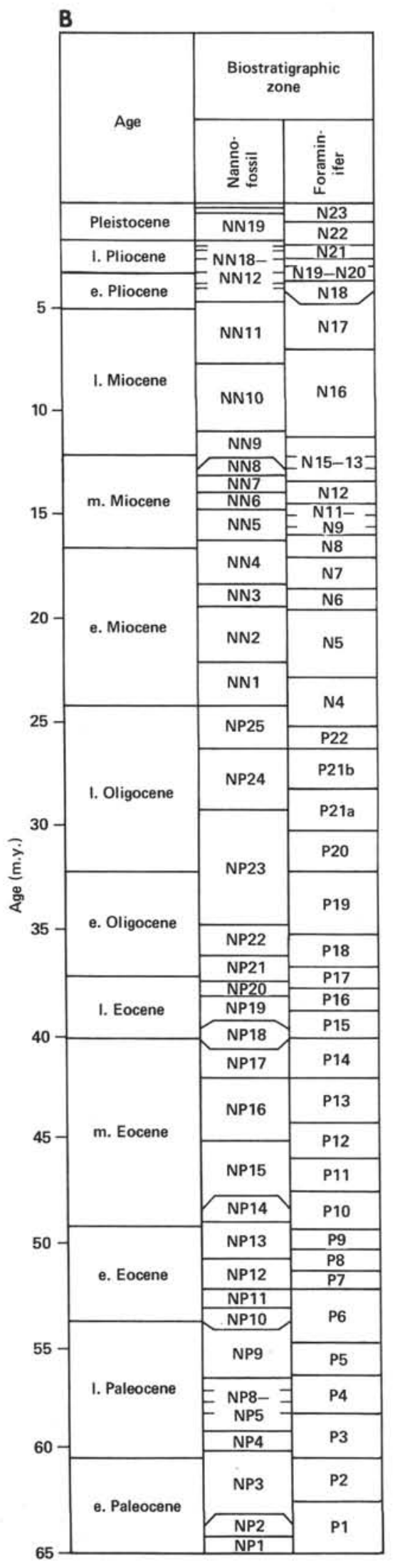

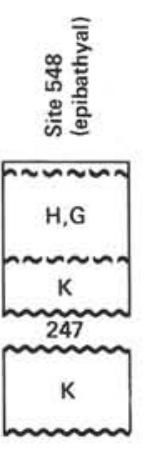

305

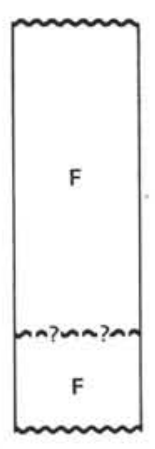

352

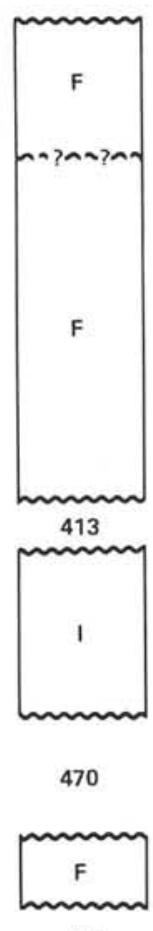

471
Tertiary

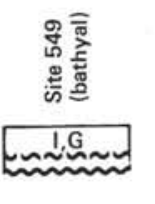

27

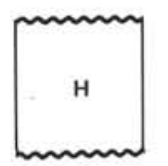

47
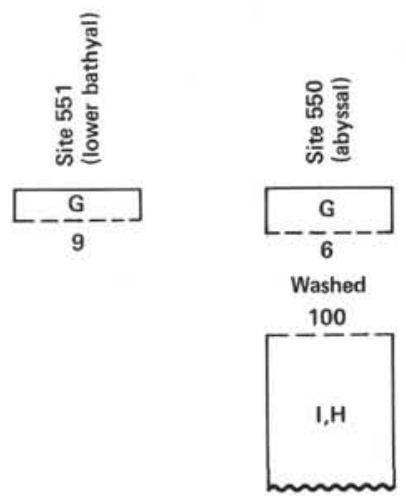

255

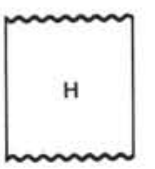

50

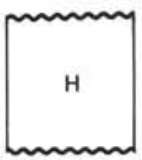

$\frac{\text { g }}{\frac{5}{5}}$

K

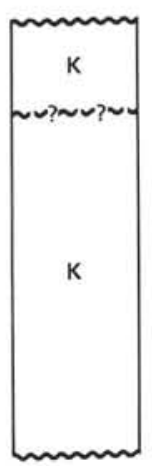

310

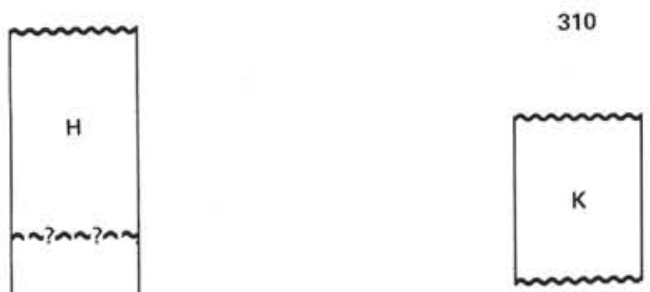

311

I.H
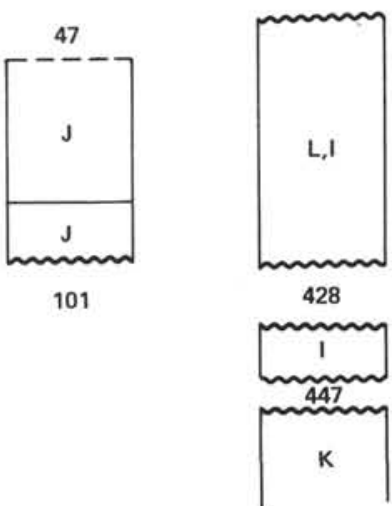

Figure 1. (Continued). 
Berggren et al. (in press) are compiling first-order biostratigraphic datum levels against magnetic stratigraphy to update the Cenozoic time scale. In connection with this compilation, estimates of the absolute ages of some magnetostratigraphic and biostratigraphic "events" are likely to be modified. For example, previous correlations of biostratigraphy and age estimates for the lower/ middle Eocene boundary are probably incorrect (Berggren, pers. comm., 1982). It is beyond the scope of this summary to propose new correlations among biostratigraphy, magnetostratigraphy, geochronology, and absolute dating. Therefore, we have simply adopted the absolute ages suggested by Hailwood et al. (1979), with the full understanding that some modifications are imminent. This approach will provide a suitable frame of reference for interpreting our data and for relating them to any future changes. It will also simplify the comparisons that will certainly be made with results from Leg 48 (Bay of Biscay).

The next section of the chapter, "Unconformities," presents an overview of the sediment sections encountered at each of the four drill sites. Following that are sections on pre-rift sequences, syn-rift and post-rift sequences of the Cretaceous, and Tertiary and Quaternary sequences. The "Summary" section reviews the chronology of major "events," and provides the generalized geological history for each site.

\section{UNCONFORMITIES}

Among the major objectives of Leg 80 was the investigation of numerous seismic unconformities, all of which have been dated biostratigraphically (Müller; Snyder and Waters; Magniez and Sigal; all this vol.). In addition, several less pronounced unconformities, many involving a hiatus too short to be resolved biostratigraphically, were noted during inspection of the cores. The basic sedimentary pattern associated with most unconformities was a coarser, often turbiditic deposit overlying a more homogeneous pelagic unit, often a chalk (Poag et al., this vol.). All unconformities referred to hereafter are plotted on Figure 1B.

\section{Site 548}

Hercynian basement rocks (middle to upper Devonian) composed of unfossiliferous gray quartzites and shiny black shales (Lefort, this vol.) are encrusted with a phosphatic, calcareous hardground that appears to represent a long period of slow deposition characterized by upwelling (Karpoff et al., this vol.). This phosphatic crust is unconformably overlain by upper Campanian chalks. Cretaceous sediments above the unconformity represent continuous deposition from the late Campanian through the late Maestrichtian.

The Cretaceous/Tertiary boundary is marked by a hiatus representing the earliest Paleocene; planktonic foraminiferal Zones P1a through P1c and nannofossil Zones NP1 and NP2 are missing. Another unconformity (hiatus of about 4 m.y.) occurs within the middle Paleocene. Lower Eocene marly nannofossil chalks are unconformably overlain (hiatus of 1-2 m.y.) by middle Eocene silty nannofossil chalks. There may be minor un- conformity at the Eocene/Oligocene boundary (Miller et al., this vol.), but recovery was poor through this interval and the evidence is not conclusive. There is a middle Oligocene hiatus, representing perhaps 3 to $4 \mathrm{~m} . \mathrm{y}$., that spans parts of nannofossil Zones NP23 and NP24. The Oligocene section is extremely condensed, and planktonic foraminiferal evidence regarding this unconformity is equivocal. One or two very minor unconformities may exist within the upper Oligocene section (Miller et al., this vol.). The youngest major unconformity (hiatus of about 5 m.y.) at Site 548 separates middle Miocene nannofossil chalk from upper Miocene laminated mudstone. Sedimentary and benthic foraminiferal evidence indicates an upper Miocene erosional unconformity (within planktonic foraminiferal Zone N17) representing a span of perhaps slightly more than 1 m.y. (Poag and Low, this vol.). Poag and Low also recognize a minor middle Pliocene unconformity (within Zone N19/N20). Neither of these unconformities was recognized during surveys of planktonic foraminifers and nannofossils, but each conforms to a drop in sea level on the curve of Vail and Hardenbol (1979). Nannofossil evidence suggests a minor hiatus during the Quaternary; the lowest part of Zone NN20 appears to be missing.

\section{Site 549}

Hercynian basement rocks at Site 549 (Devonian or lower Carboniferous) are composed of fine- to mediumgrained, laminated and cross-laminated sandstones with vertically oriented cleavage planes (Lefort, this vol.). Lying unconformably upon the basement are interbedded terrigenous and calcareous syn-rift mudstones of the Barremian and possibly, in part, the Hauterivian. Capping this thick (290-m) syn-rift sequence is the "breakup" unconformity (hiatus of about 9 m.y.) that spans most of the Aptian and possibly part of the lower Albian. A thin $(9.7-\mathrm{m})$ sandy dolosparite which underlies the unconformity has not yet been dated, but it appears to represent Aptian syn-rift deposition; a thick post-rift Albian section lies above. Foraminiferal studies reveal a middle Albian through early Cenomanian hiatus. A similar hiatus is well known from other sites in the North Atlantic (de Graciansky et al., 1982). Although nannofossil evidence is equivocal, foraminiferal studies suggest that the upper Cenomanian section is missing. Nannofossil evidence indicates that the middle part of the Maestrichtian is also missing.

The Cretaceous/Tertiary boundary at Site 549 is marked by an unconformity (hiatus of about $4 \mathrm{~m}$.y.) that represents most of the early Paleocene. Nannofossil evidence indicates a shorter hiatus (about $1 \mathrm{~m} . \mathrm{y}$.) during the early part of late Paleocene time. Nannofossil Zone NP10 (lower Eocene) is unusually thin at this site. In addition, 41 thin bentonite layers recognized at this level in Hole 550 are not present at Site 549, suggesting that part of Zone NP10 is missing (Knox, this vol.). A minor unconformity has also been tentatively identified near the middle/upper Eocene boundary by Miller et al. (this vol.). Their interpretation is confirmed by the extremely thin section assignable to nannofossil Zone NP17. 
The very thin sediment section representing nannofossil Zone NP23 indicates that a middle Oligocene unconformity is present (hiatus of 4-5 m.y.). As at Site 548, planktonic foraminiferal evidence is equivocal. A major unconformity (hiatus of about $5 \mathrm{~m}$.y.) represents the latest Oligocene and part of the early Miocene. The rather abbreviated Miocene section is interrupted by another unconformity (hiatus of a least 5 m.y.) that separates middle Miocene from upper Miocene sediments. Another major unconformity (hiatus of at least 3.5 m.y.) separates the upper Miocene and the Pleistocene sections. The associated hiatus spanned the entire Pliocene and a portion of the early Pleistocene (the lower part of nannofossil Zone NN19 is missing). An abrupt lithologic and planktonic foraminiferal faunal change within the Pleistocene (between Cores 2 and 3, Hole 549A) suggests a probable sediment gap (Pujol and Duprat, this vol.), but the duration of the hiatus has not been estimated.

\section{Site $\mathbf{5 5 0}$}

Basement rocks at Site 550 are basalt flows and pillows interbedded with deep-water pelagic carbonates which appear to have been deposited no earlier than the late Albian. The sediments immediately above the youngest pillows are upper Albian. A relatively thick, continuous upper Albian through middle Cenomanian sequence is capped by an unconformity overlain by Coniacian/Santonian deposits. The latter sequence is, in turn, unconformably(?) overlain by younger sediments (probably Campanian) that were deposited below the carbonate compensation depth. A thick, apparently continuous Maestrichtian section completes the Cretaceous sequence.

The Cretaceous/Tertiary boundary lies within a sequence of abyssal chalks. The boundary was not recovered in Hole 550, where nannofossil Zone NP3 and foraminiferal Zone P1d appear to lie immediately upon upper Maestrichtian sediments. However, recovery through the interval containing the boundary was rather poor. Recovery was better in Hole 550B, where the presence of Eoglobigerina eugubina, an indicator of foraminiferal Zone P1a, suggests that the Cretaceous/Tertiary boundary is conformable. Basal Tertiary nannofloral associations have also been recognized in this interval, which consists of turbiditic layers containing lowermost Paleocene and Maestrichtian reworked microfossils. Two hiatuses, one uppermost lower Paleocene (suggested by the absence of foraminiferal Zone P2) and one upper Paleocene (suggested by nannofossil evidence in an interval where dissolution has almost completely destroyed foraminifers), interrupt the Paleocene sequence. Sediments containing lower Eocene planktonic foraminifers are separated from those containing the lower Miocene assemblages by an interval barren of foraminifers which, according to nannofossil evidence, contains a condensed uppermost middle to upper Eocene and a partial Oligocene sequence. There is a middle Eocene unconformity in which nannofossil Zone NP17 overlies Zone NP14. A major Oligocene unconformity (hiatus of at least $5 \mathrm{~m} . \mathrm{y}$.) separates sediments of Zone NP21 from those of NP24/
NP25. Higher in the section, the absence of nannofossil Zone NN4 indicates a possible lower/middle Miocene hiatus, but assemblages from this zone could lie within a 1.2-m unsampled interval. The youngest major unconformity (hiatus of 4-5 m.y.) at this site separates middle from upper Miocene sediments. The post-Pliocene record is incomplete because continuous coring was not initiated until $100 \mathrm{~m}$ below the seafloor.

\section{Site 551}

The basement complex of basaltic flows and pillows is overlain by an abbreviated Cretaceous sequence ( 41.5 $\mathrm{m}$ thick) at Site 551. Hiatuses and, to a lesser extent, reduced sedimentation rates are responsible for the condensed Cretaceous section. Upper Cenomanian chalks, which lie directly upon basaltic basement, are overlain by lower Turonian deposits, including black shale rich in organic matter. A major unconformity (hiatus of about 20 m.y.) separates Turonian from upper Campanian sediments. An apparently continuous upper Campanian through lower Maestrichtian sequence is unconformably overlain by upper Paleocene sediments (nannofossil Zone NP9, undifferentiated upper Paleocene, according to evidence of planktonic foraminifers). A hiatus representing at least $14 \mathrm{~m}$.y. exists at this contact.

The Tertiary section at Site 551 is represented by only three cores, taken at widely spaced intervals. A condensed section of uppermost Paleocene to lowermost middle Eocene sediments is present, but detailed biostratigraphic information on the entire sequence is not available.

\section{PRE-RIFT SEQUENCES}

Hercynian basement rocks at Site 548 comprise a few large chips (up to $10 \mathrm{~cm}$ ) of unfossiliferous gray quartzite and shiny black shale (Lefort, this vol.). The shale contains middle Devonian planktonic acritarchs and fragments of plant tissues and spores. This quartziteshale sequence probably accumulated in coastal to shallow marine environments.

At Site 549, no fossils were recovered from the basement strata, which consist of fine- to medium-grained, laminated and cross-laminated sandstones, rose, brown, or gray, superficially resembling the "Old Red Sandstones." The composition, mild diagenesis, and $\mathrm{Rb} / \mathrm{Sr}$ measurements on muscovites suggest equivalence to the Devonian-lower Carboniferous sequence of Ireland (Lefort, this vol.).

\section{SYN-RIFT SEQUENCES}

Syn-rift strata were penetrated at Site 549 . The section includes $9.7 \mathrm{~m}$ of possibly Aptian dolosparite lying unconformably above $290 \mathrm{~m}$ of Barremian/Hauterivian(?) siliciclastic and bioclastic strata, which rest on Hercynian basement (Fig. 2).

\section{Barremian-Hauterivian(?)}

A long normal-polarity interval characterizes the entire Barremian/Hautervian(?) section. Only one short polarity reversal was detected ( $880 \mathrm{~m}$ sub-bottom), indicating that the base of the Cretaceous quiet zone proba- 
Late Cretaceous

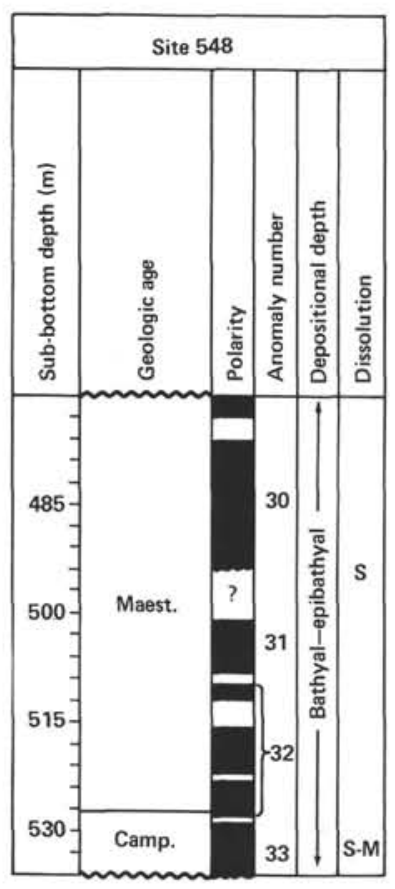

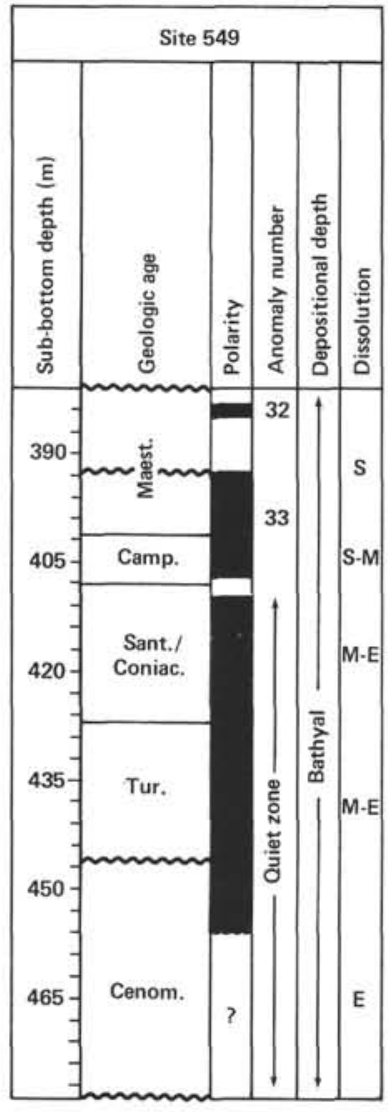

Early Cretaceous

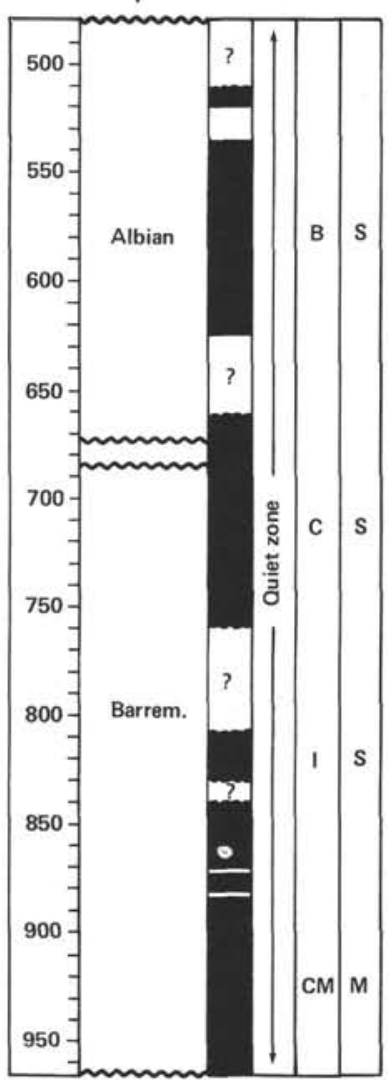

\begin{tabular}{|ll|}
\hline \multicolumn{2}{|c|}{ Legend } \\
\hline CM & Coastal marine (brackish) \\
I & Infralittoral \\
C & Circalittoral \\
B & Bathyal \\
LB-A & Lower bathyal to abyssal \\
S & Slight \\
M & Moderate \\
\hline
\end{tabular}
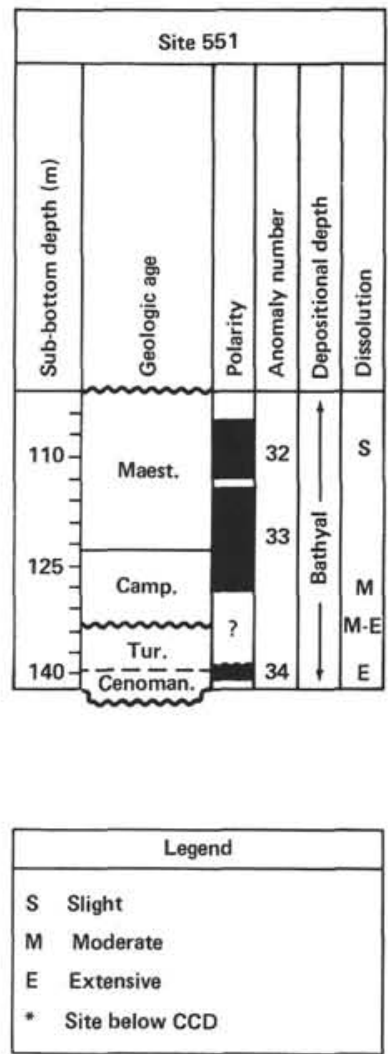

Figure 2. Graphic summary of the Cretaceous. 
bly was not reached at Site 549 (Townsend, this vol.). According to the polarity time scale of van Hinte (1976), sediments immediately above the basement would thus be no older than Barremian. On the other hand, microfossil data do not rule out the possibility that the basal strata may be upper Hauterivian (Magniez and Sigal, this vol.).

Detailed analyses of sediment composition, texture, $\mathrm{X}$-ray mineralogy, and microfossil and macrofossil assemblages (both plant and animal) have revealed a complex depositional and environmental history for the synrift strata (Müller; Magniez and Sigal; Mazzullo et al.; Batten; Borkowski and Muzzullo; Rat et al.; all this vol.). Three basic depositional/environmental facies are represented, but several subfacies are obvious as well.

Strata of the first facies (956 to $852 \mathrm{~m}$ sub-bottom) rest upon the basement, and are dominantly well-sorted terrigenous clastics. The fossil content is sparse at the base, but higher beds contain shell debris (e.g., oysters), echinoderms, sponges, worm tubes, calcareous algae, and benthic foraminifers (chiefly agglutinated species of Choffatella and Haplophragmium). The general taxonomic compositions of these assemblages and their sparsity and low diversity suggest that they accumulated in shallow coastal environments. The dominant foraminifers are typical of hyposaline conditions. Some of the algae are types that need strong light concentration and are good indicators of shallow, clear water. Abundant terrigenous plant debris, spores, and pollen within this unit indicate deposition close to a landmass covered with mixed pteridophyte-gymnosperm vegetation growing in a relatively warm climate.

The second syn-rift depositional facies ( 852 to $755 \mathrm{~m}$ sub-bottom) reflects increasingly marine conditions, and is characterized by abundant carbonate within a series of bioclastic siltstones, silty limestones, and oncolitic grainstones. The marine fossil content is more abundant and varied, including bryozoans, bivalves, brachiopods, gastropods, corals, worm tubes, calcareous algae, and benthic foraminifers. The foraminiferal assemblage is dominated by Trocholina (a shallow-marine form) and a variety of encrusting species. These characteristics suggest a shallow carbonate-shelf environment. Changes in the nature and abundance of organic debris also suggest increasing marine influence.

The third facies ( 755 to $674 \mathrm{~m}$ sub-bottom) is marked by the return of abundant terrigenous detritus (silt and clay) and the introduction of planktonic and abundant calcareous benthic foraminifers. Bioclasts include mollusk and echinoderm fragments, sponge spicules, and belemnites. The presence of planktonic foraminifers is especially characteristic of open marine conditions, and their relative abundance argues for relatively great, perhaps bathyal, depths.

\section{Aptian}

The presence of Aptian sediments at Site 549 has not been firmly established. Circumstantial evidence suggests, however, that the 9.7-m-thick red, sandy dolosparite at 664.15 to $673.85 \mathrm{~m}$ sub-bottom may be a rem- nant of Aptian deposition. The predominant components (dolomite, quartz, calcite, hematite, plagioclase feldspar, clay minerals, volcanic rock fragments, foraminifers, echinoid plates) suggest deposition in littoral to outer sublittoral environments. Later cementation took place in brackish and fresh-water paralic continental environments. The dolosparite is bounded below and above by an unconformity created during subaerial exposure, as indicated by the dolomitization and hematization of the rock (Borkowski and Mazzullo, this vol.). Thus, this unit appears to lie directly beneath the postrift unconformity, and therefore to be part of the synrift sequence. Further, the dolosparite appears to be contiguous with a thick syn-rift sequence that can be seen to the northeast of Site 549 on seismic reflection profiles. The position of this syn-rift sequence above the Barremian sequence and below the post-rift unconformity is strong evidence that it is Aptian.

\section{POST-RIFT SEQUENCES}

\section{Albian}

Albian strata were encountered at two sites, 549 and 550. The thick, nearly complete Albian section at Site 549 is characterized by normal polarity within the Cretaceous quiet zone (Fig. 2). A short polarity reversal occurs in the middle Albian sequence, but poor recovery prevented recognition of any patterns in the lower and upper Albian. Three short reversals detected in probable upper Albian sediments from Site 550 may represent the upper Albian mixed-polarity interval (van Hinte, 1976; Hailwood et al., 1979). This interpretation is broadly consistent with biostratigraphic evidence.

Biostratigraphic studies document the presence of an uppermost lower Albian and a thick middle Albian sequence at Site 549. A single relatively homogeneous formation and foraminiferal fauna characterize the entire section. The overall foraminiferal association is relatively diverse, although the benthic species are somewhat less so than at comparable stratigraphic levels in other geographic regions (e.g., marine basins in Europe, numerous oceanic sites). The abundance of planktonic foraminifers and radiolarians indicates an open-marine influence and deposition in a middle to lower bathyal environment. Nannofloral associations suggest less homogeneity, with alternations through the middle Albian that may reflect climatic fluctuations. Sporadic increases in the relative abundance of radiolarians suggest that periodic upwelling may have occurred (Waples, this vol.). However, Albian strata contain very little organic matter; deposition took place in moderately well oxygenated environments (Batten et al.; Waples; de Graciansky and Gillot; all this vol.).

Nannofloral and foraminiferal evidence indicates the presence of a thin sequence of upper Albian pelagic carbonates at Site 550 . These lower bathyal to abyssal carbonates immediately overlie and are interbedded with basalt flows and pillows.

Post-rift Albian sediments indicate the presence of a developing deep-water seaway in the Goban Spur re- 
gion. Site 549 had subsided to middle bathyal depths, whereas marine deposition at Site 550 was initiated at lower bathyal to abyssal depths (Masson et al., this vol.).

\section{Cenomanian}

Cenomanian sediments were encountered at Sites 549, 550 , and 551. All intervals where recovery was sufficient to permit paleomagnetic analysis were characterized by an uninterrupted pattern of normal polarity (Fig. 2).

Cenomanian sediments at Sites 549 and 551 contain nannofossils that have been extensively fragmented and partially dissolved during diagenesis. Concomitant dissolution of siliceous microfossils resulted in the formation of biogenic opal-CT at Site 549, and probably contributed to the formation of zeolites (clinoptilolite) at Site 551. Preservation is somewhat better at Site 550, where extensive dissolution/recrystallization was limited to discrete layers.

Despite gaps in the stratigraphic record, resulting from disconformities in portions of the Cenomanian at several sites, deposition appears to have taken place in well-oxygenated environments that were far offshore. The only exception to this pattern is indicated by the presence of several laminated black shales and numerous carbonaceous silty mudstones (6 to $30 \mathrm{~cm}$ thick) at Site 550. Their increased TOC, of chiefly marine origin, indicates that deposition must have occurred in oxygendepleted conditions (Waples; de Graciansky and Gillot; Cunningham and Gilbert; all this volume).

\section{Turonian}

A distinct but thin sequence of Turonian black shales rich in organic matter $(8-11 \%$ TOC) occurs at Sites 549 and 551. These layers, observed also at other sites in the North Atlantic (de Graciansky et al., 1982), correspond to an anoxic event which interrupted well-oxygenated conditions reflected in the remainder of the Upper Cretaceous sequence. This anomalous anoxic event was associated with a major marine transgression and a period of widespread volcanic activity (Müller, this vol.). Diagenetic processes have destroyed much of the nannoflora within these organic-carbon-rich deposits, but interbedded white chalks have been reliably dated as Turonian.

\section{Santonian Coniacian}

Santonian/Coniacian sediments, present only at Sites 549 and 550, were deposited near the end of the Cretaceous magnetic quiet period; they are characterized by normal polarity (Fig. 2). One brief magnetic reversal was noted at Site 550. Biostratigraphic subdivision of the condensed Santonian/Coniacian sections was not possible. Nannofossils are common at Site 549, but have generally been fragmented during diagenesis; they are absent from the lower part of this interval at Site 550, possibly because sediments accumulated below the carbonate compensation depth. The unconformity separating Santonian/Coniacian deposits from underlying Cenomanian sediments was confirmed by foraminiferal studies.

\section{Campanian}

At least some portion of the Campanian Series appears to be present at each of the four Leg 80 sites. It is consistently associated with a normal-polarity episode that has been identified as Anomaly 33 (Fig. 2).

A condensed sequence of abyssal Campanian sediments has been tentatively identified at Site 550. Microfossil evidence is lacking because of probable deposition below the carbonate compensation depth; identification is based on the presence of a paleomagnetic anomaly that is elsewhere associated with Campanian assemblages. A condensed but apparently complete section occurs at Site 549, whereas only upper Campanian strata are present at Sites 551 and 548. Upper Campanian sediments appear to be transgressive upon Hercynian basement rocks at Site 548. Microfossil data suggest that initial Campanian deposits at Site 548 accumulated in less than $500 \mathrm{~m}$ of water (Magniez and Sigal, this vol.). Structural and geophysical constraints suggest, however, that the initial Campanian water depth at Site 548 exceeded $500 \mathrm{~m}$ (Masson et al., this vol.). Before the initial Campanian deposition, there appears to have been at Site 548 a long period of slow deposition, which allowed encrustation of a phosphatic, calcareous hardground upon the Devonian basement. The hardground is undated, but its phosphatic content indicates upwelling at this site during the encrustation (Karpoff et al., this vol.).

\section{Maestrichtian}

Sequences abbreviated primarily by unconformities represent the Maestrichtian Stage at Sites 549 and 551. A somewhat condensed but apparently complete Maestrichtian section is present at Site 548; a thicker, continuous sequence occurs at Site 550. Only magnetic Anomaly 32 has been recognized in the abbreviated sections, but Anomalies 30 to 32 can be identified at Sites 548 and 550 (Fig. 2).

The effects of dissolution are slight in this portion of the Upper Cretaceous section, even in sediments which accumulated at abyssal depths (Site 550). Both nannofossil and foraminiferal associations at Site 548 indicate an outer-shelf to upper-slope depositional environment. More seaward sites were of course situated at correspondingly greater depths.

\section{THE TERTIARY}

Significant accumulations of Tertiary sediments were continuously cored at Sites $548(471 \mathrm{~m}), 549(381 \mathrm{~m})$, and $550(469 \mathrm{~m})$. The abbreviated Tertiary section at Site $551(100 \mathrm{~m})$ was not continuously cored; in addition to the mudline core, only two cores, one near the middle and one at the base of the Tertiary section, were recovered. Consequently, Site 551 has not been included in most segments of the following discussion.

Despite similar thicknesses of the overall Tertiary section at three of the sites, there are pronounced differences in the stratigraphic thicknesses of individual series comprising this system (see fig. 7 of Snyder and Waters, this vol.). These differences result from (1) the positions 
of the sites at various points along the continental margin and abyssal plain, and (2) the different positioning of the sites within their respective half-grabens. Refer to Figures 3 and 4 during the following discussion.

\section{Paleocene}

Portions of the Paleocene are present at all Leg 80 sites, although the section at Site 551 is only several centimeters thick. Magnetic susceptibility and the intensity of remanent magnetism are generally high, particularly at Site 550. Both the lowermost and the middle Paleocene are absent at Site 548. The resultant Paleocene section is too abbreviated and too condensed to permit unequivocal paleomagnetic interpretation. Magnetic Anomalies 25 and 26 have been recognized within the upper Paleocene sediments at Site 549, but the lower Paleocene section is incomplete and extremely condensed (Fig. 3). Despite unconformities in both its lower and upper portions, the Paleocene stratigraphic sequence at Site 550 is more complete than at other Leg 80 sites. Magnetic Anomalies 25 through 27 have been recognized in Hole 550, but the identification of Anomalies 28 through 30 is tentative. Fortunately, Anomalies 28 and 29 can be confidently recognized in Hole $550 \mathrm{~B}$; the Cretaceous/Tertiary boundary lies within the reversedpolarity episode preceding Anomaly 29 (Fig. 3).

Upper Paleocene sediments (nannofossil Zone NP8) at Site 549 contain a dark gray, friable, fine sand that represents an altered volcanic ash (Knox, this vol.). Similar ashes occur at a similar stratigraphic level in the North Sea area (Knox and Morton, in press).

Well-preserved, low-diversity lower Paleocene associations characterize both nannofossils and planktonic foraminifers at Sites 548 and 549, indicating relatively cool surface waters. Extensive dissolution of microfossils within several upper Paleocene horizons at Site 550 suggests deposition below the CCD. The middle Paleocene hiatus identified at all Leg 80 sites is widely recognized (Leg 48, northwestern European Tertiary basins). Poag et al. (this vol.) examined changes across the lower/upper Paleocene unconformity at Site 548. Significant changes upward across the unconformable contact include an increase in grain size and clay content, a decrease in $\delta^{18} \mathrm{O}$ and $\delta^{13} \mathrm{C}$, a decrease in benthic foraminiferal diversity, and an increase in the percentage of benthic foraminifers relative to other microfossils. Before
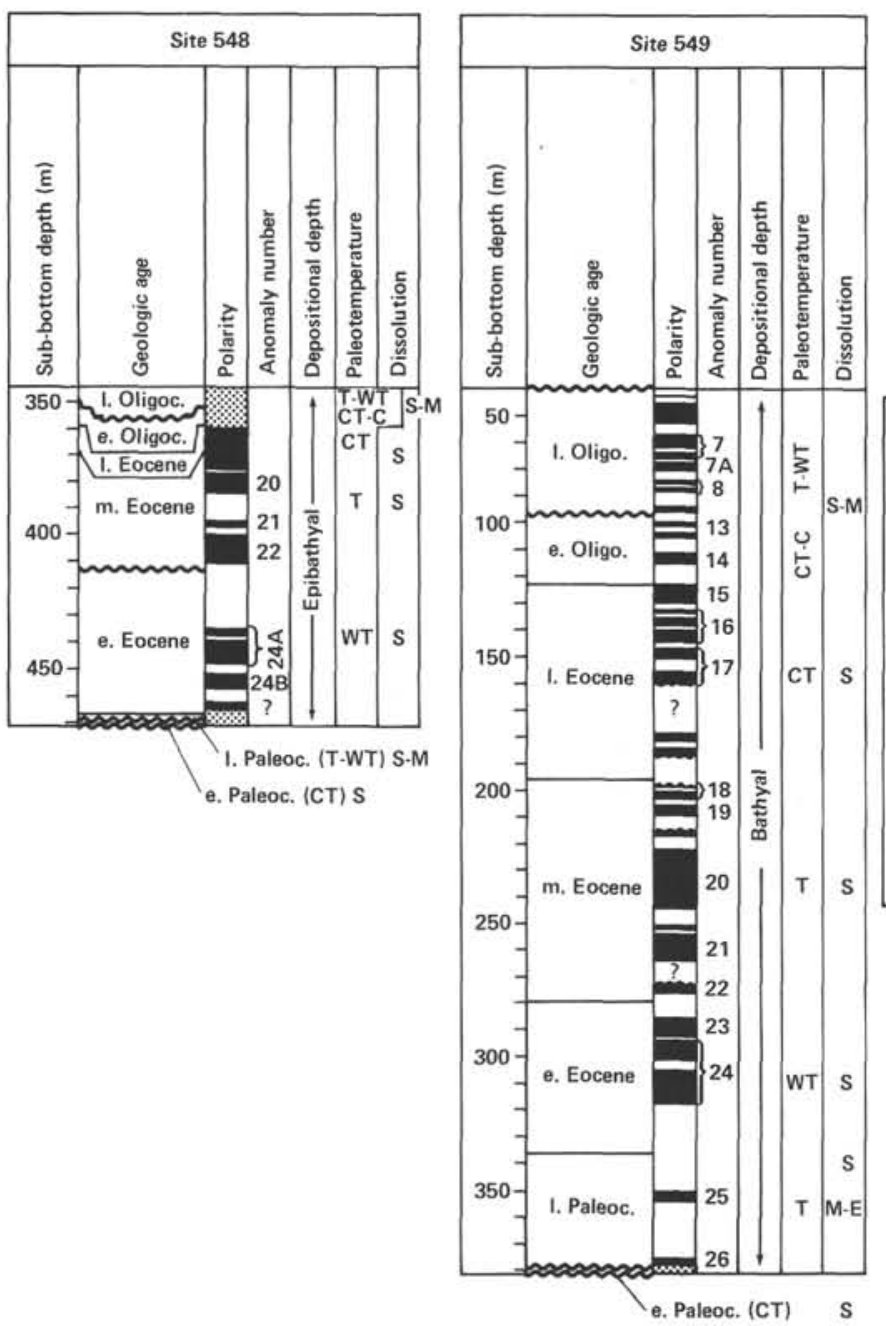

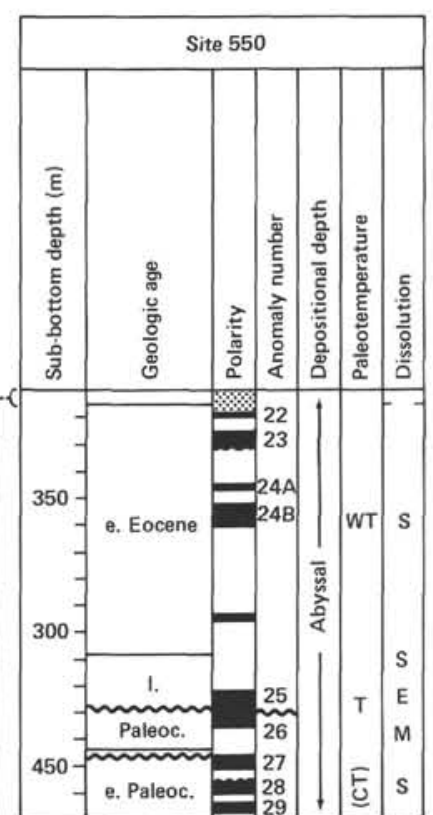

I. Oligoc.7 (T) e. Oligoc. (CT-C) S-M

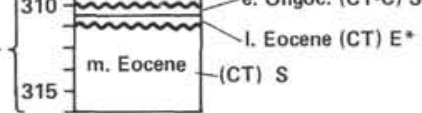

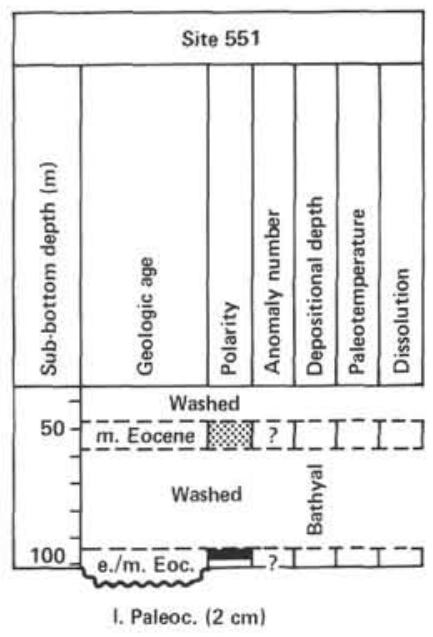

\begin{tabular}{|c|c|}
\hline & Legend \\
\hline & Unreliable data \\
\hline WT & Warm temperate \\
\hline $\mathrm{T}$ & Temperate \\
\hline CT & Cool temperate \\
\hline C & Cold \\
\hline $\begin{array}{l}S \\
M\end{array}$ & $\begin{array}{l}\text { Slight } \\
\text { Moderate }\end{array}$ \\
\hline$E$ & Extensive \\
\hline * & Site below CCD \\
\hline
\end{tabular}

Figure 3. Graphic summary of the early Tertiary (Paleogene). 

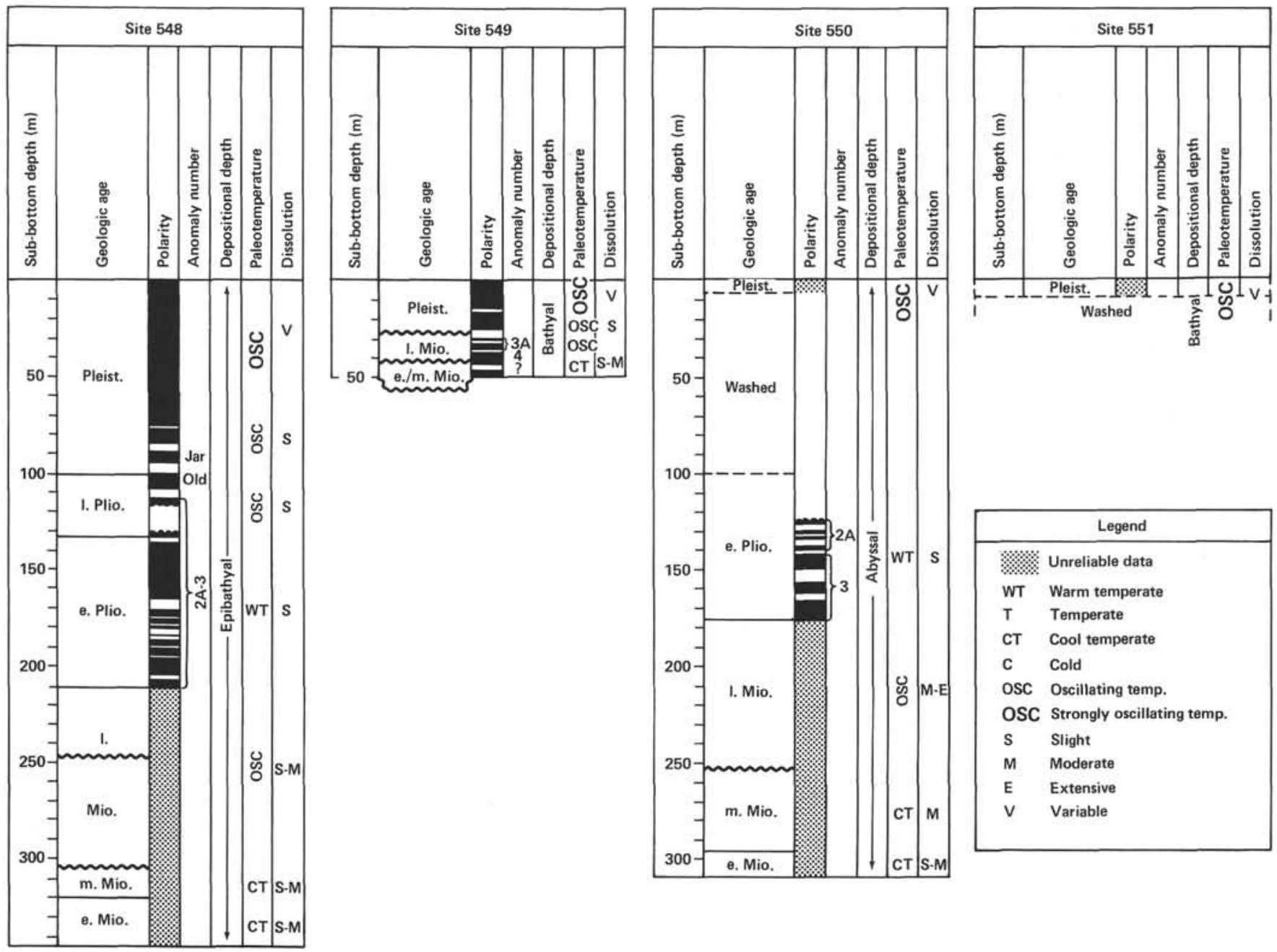

Figure 4. Graphic summary of the late Tertiary and Quaternary (Neogene). (Jar = Jaramillo event; Old $=$ Olduvai event.)

the sea-level fall corresponding to the hiatal interval, bottom conditions were well oxygenated, relatively cool, and situated at epibathyal depths. Post-hiatal deposition resumed in the form of turbidites displaced from adjacent areas of the slope, after which warmer bottom-waters became established. Upper Paleocene planktonic foraminiferal associations, marked by an increase in Morozovella and Acarinina relative to Subbotina, indicate warmer surface waters. Higher-diversity, warmerwater nannofloral associations also characterize upper Paleocene sediments at Sites 548 and 549, where there is a corresponding increase in siliceous microfossils.

\section{Eocene}

The Eocene section at Site 548, which is interrupted by a major unconformity at the lower/middle Eocene boundary, is moderately thick. Magnetic Anomalies 2022, 24A, and 24B have been recognized, but Anomaly 23 is absent owing to the unconformity (Fig. 3). The change from marly sediments to chalks across this contact correlates with decreases in the intensity of remanent magnetism and the volume susceptibility, and it marks the end of an increased supply of volcanic material during the early Eocene. There is a normal-polarity interval within nannofossil Zone NP10 that does not correlate with any specific magnetic anomaly on the standard scales. Magnetic Anomalies 15 to 24 are present in the thick, essentially continuous Eocene section at Site 549. Results from a significant portion of this section are somewhat tentative because they are based solely on NRM measurements. Eocene sediments at Site 550 lie largely within the lower part of that series. NRM intensities and volume susceptibilities are notably higher than in younger sediments at this site, and magnetic Anomalies 22 to $24 \mathrm{~B}$ have been recognized. No meaningful paleomagnetic patterns are discernible in Hole 551, owing to a lack of sampling.

Nannofossil associations from lower Eocene sediments at all Leg 80 sites are highly diverse and indicate relatively warm surface water. In the uppermost lower Eocene (nannofossil Zones NP13 and NP14) at Site 550 , compositional changes in the assemblages mark a slight decrease in surface water temperature. The lower Eocene section at Site 548 is terminated by an unconformity representing a hiatus of about 2 m.y. (nannofossil Zone NP13 is missing). Among planktonic foraminifers, an abrupt decrease in the abundance of Acarinina, coupled with an inverse trend in Subbotina, also sug- 
gests that surface waters cooled in the latest early Eocene. According to Poag et al. (this vol.), lower Eocene deposits at Site 548 accumulated in a well-oxygenated, relatively warm, epibathyal environment. The bottom environment began to shift toward significantly cooler conditions just before a major sea-level fall that correlates with the hiatus. Brown and Downie (this vol.) recognize an impoverished association of dinoflagellate cysts in the lower Eocene of Site 548. It is similar in some respects to lower Eocene Zones II and III on Rockall Plateau (Costa and Downie, 1979). Pollen is primarily from gymnosperms, indicating deposition far from any shoreline. The magnetic fabric of Goban Spur sites indicates that the early Eocene depositional regime differed from other periods studied within this region, because magnetic grains are aligned parallel to the continental slope. In contrast, grain alignment is perpendicular to the slope in all other stratigraphic sections. Thus, a regime of contour currents may have been established along Goban Spur in the early Eocene (Hailwood and Folami, this vol.).

Disseminated globular volcanic ash particles are common in the lower Eocene at Site 550 (Knox, this vol.). Numerous discrete bentonite layers, each 2 to $3 \mathrm{~cm}$ thick, are present in the basal part of this section. Disseminated ash particles also occur in the lower Eocene at Site 549 , but discrete bentonite layers comparable to those at Site 550 have not been recognized. As discussed previously, their absence is probably due to an unconformity in which part of nannofossil Zone NP10 is missing. Comparable bentonites have been identified, however, in sediment from Hole 401 (Leg 48), in the North Sea, and in the Rockall area. On the basis of regional trends in their distribution, number, and thickness and of general compositional similarities among their plagioclases, Knox suggests that the lower Eocene ashes in the Goban Spur area are distal representatives of explosive volcanism that affected the entire northeastern Atlantic.

Middle Eocene sediments at Sites 548 and 549 accumulated in cool temperate waters at epibathyal to bathyal depths. Significant upsection changes across the lower/middle Eocene unconformity at Site 548 include an increase in grain size, heavier values for $\delta^{18} \mathrm{O}$ and $\delta^{13} \mathrm{C}$, and an increase in benthic foraminiferal faunal diversity (Poag et al., this vol.). Compared with the lower Eocene, middle Eocene sediments were deposited in cooler water and environments slightly more offshore. A decrease in the abundance of Morozovella and a corresponding increase in Acarinina among planktonic foraminiferal associations indicate that surface waters were also cool. Site 550 was below the carbonate compensation depth during much of the middle and late Eocene.

The upper Eocene section at Site 548 is condensed, and that at Site 550 is incomplete because of an unconformity; a clear record of upper Eocene trends is recorded in the thick stratigraphic section at Site 549. Gradual cooling of surface waters is suggested by changes in the nannofloral associations. However, changes in planktonic foraminiferal diversity and dominance, coupled with small isotopic changes, may indicate increased productivity rather than a temperature decrease (Loubere, this vol.). In the upper Eocene interval there are major changes in benthic foraminiferal assemblages, including abundance changes among predominant species and first- and last-appearance datums for several species (Miller et al., this vol.). The effect on the overall benthic foraminiferal fauna is one of gradual change, which corresponds to a major $\delta^{18} \mathrm{O}$ increase that began in the latest Eocene. Miller et al. (this vol.) cite these events as evidence for the initiation of vigorous bottomwater flow-manifested by a late Eocene erosional episode at most North Atlantic localities-during which old, warm, corrosive, sluggishly circulating bottom water was replaced by younger, colder, more vigorously circulating bottom water from a northern source.

There is a thin $(2-\mathrm{cm})$ volcanic ash layer in the upper Eocene section (nannofossil Zone NP18) at Site 549 (Knox, this vol.). It is composed of colorless, fine sand disseminated through nannofossil oozes. The episode responsible for this ash is not so widely recognized as the Paleocene and early Eocene episodes, but it may have been part of the volcanic activity occurring in Iceland in the late Eocene (Karpoff et al., this vol.).

The planktonic foraminifer- and nannofossil-based identifications of the Eocene/Oligocene boundary at Site 549 do not coincide. This discrepancy is discussed in detail by Snyder et al. (this vol.). Regardless of which interpretation is utilized, there are no dramatic faunal or floral changes at this series boundary. The pattern is one of gradual change through the upper Eocene and lower Oligocene, similar to that noted by Corliss $(1979,1981)$ and Tjalsma and Lohmann (1983).

\section{Oligocene}

Paleomagnetic sequences in the Oligocene Series of Leg 80 sites have been difficult to interpret (Fig. 3). No conclusive magnetic polarity reversal sequence could be defined at Site 548. Magnetic Anomalies 7, 7A, 8, 13, and 14 , as well as several polarity reversals that have not been identified, occur at Site 549. Results at this site are based largely on NRM measurements, however, and the assignment of magnetic anomaly numbers is tentative. Interpretations have relied heavily upon biostratigraphy to define gaps in the sequence. No magnetic data are available for the Oligocene at Site 550 .

The vigorous cold-water circulation which began during the late Eocene culminated in a rapid cooling event during the early Oligocene. Abrupt increases in $\delta^{18} 0$ and $\delta^{13} \mathrm{C}$ occur just above the Eocene/Oligocene boundary at Site 549 (Miller et al., this vol.). Lower Oligocene nannofossil and planktonic foraminiferal associations are of low diversity, and contain species indicating cool surface waters and decreased primary productivity. Condensed sections and some sort of middle Oligocene hiatus occur at all continuously cored Leg 80 sites. The hiatal interval correlates roughly with a major drop in sea level on the curve of Vail and Hardenbol (1979). Poag et al. (this vol.) have examined the Oligocene unconformity (hiatus of about 4 m.y.) at Site 548. Upsection changes in grain size (greater), $\delta^{13} \mathrm{C}$ (lighter), benthic foraminiferal faunal diversity (lower), and quantita- 
tive changes among benthic species indicate a transition from well-oxygenated, relatively cool, epibathyal conditions in the early Oligocene to shallower (but still epibathyal), slightly warmer conditions in the late Oligocene. Deposition of nannofossil Zone NP24 was characterized by fluctuating water masses, as evidenced largely by the presence or absence of Chiasmolithus altus. Uppermost Oligocene nannofossil assemblages suggest a warmer-water influence associated with marine transgression. The few dinocysts present in this interval at Site 548 are similar to late Oligocene forms from the Rockall area (Brown and Downie, this vol.). There is a high percentage of wind-transported gymnosperm pollen types, indicating deposition far from any land area.

\section{Miocene}

Paleomagnetic studies of the Miocene Series at Leg 80 sites have not been productive (Fig. 4). Owing to condensed sequences in some portions of this series, and to high reversal frequencies and weakly magnetized sediments, no conclusive magnetic polarity reversal sequence could be defined at Site 548 . The highly condensed section at Site 549 made it impossible to establish the magnotostratigraphy. Unambiguous interpretation of Site 550 was not possible, because of poor recovery combined with the high frequency of geomagnetic field reversals.

There was a dramatic decrease in both the size and the diversity of nannofossils across the Oligocene/Miocene boundary, indicating a drop in surface water temperature at the onset of the Miocene. Diverse benthic foraminiferal assemblages from the lower Miocene at Site 548 indicate deposition in a well-oxygenated, epibathyal setting influenced by waters similar to the modern North Atlantic Deep Water mass (Poag et al., this vol.). Minor terrigenous sediment input, possibly the result of sediment entrapment on the continental shelf, produced condensed stratigraphic sequences at Leg 80 sites. Bolboforma, planktonic microfossils of unknown affinity which may represent algal cysts (von Daniels and Spiegler, 1974), first became conspicuous in the lower Miocene at Site 550. Their previously recorded occurrences (predominantly Miocene from the Antarctic, the Norwegian-Greenland Sea, the Bay of Biscay, Rockall Bank, Belgium, and Poland) indicate a preference for cold to cool temperate waters (Müller et al., this vol.). Marine transgression characterized the early Miocene (Vail and Hardenbol, 1979), and gradual warming coincided with rising sea level.

Lower middle Miocene sediments at Site 548 accumulated in an environment similar to that of the lower Miocene, except that higher sea level provided more stable conditions (Poag et al., this vol.). Planktonic faunal and floral assemblages suggest cooling, probably caused by growth of Antarctic ice masses (Shackleton and Kennett, 1975; Woodruff et al., 1981), during subsequent portions of the middle Miocene. The influx of colder water is marked at Site 550 by microfossil assemblages composed of Bolboforma. Upper/middle Miocene hiatuses, present at all continuously cored Leg 80 sites, were caused, in part, by vigorous bottom circulation. A ma- jor upsection decrease in the smectite/illite ratio at all Goban Spur sites, together with quartz enrichment at Site 548, may indicate increased intensity of bottom-water circulation or perhaps a change to a cooler, more humid climate (Chennaux et al., this vol.). Detailed analyses of the middle/upper Miocene hiatus at Site 548 reveal that middle Miocene sediments below the unconformity were deposited in a well-oxygenated, relatively cool and stable, epibathyal environment (Poag et al., this vol.). The hiatal interval (about 6 m.y.) corresponds to a low sea-level stand (Vail and Hardenbol, 1979).

Basal upper Miocene sediments at Site 548 were deposited within an oxygen-minimum zone, characterized by abundant and diverse bolivinids but low overall benthic diversity, at epibathyal depths (Poag et al., this vol.). Evidently, lowered sea level depressed the NADW-like water mass that previously influenced this site, replacing it with a water mass similar to the modern Mediterranean Outflow Water. Benthic foraminiferal diversity increased through the late Miocene as oxygen-enriched waters again became established. Sea level remained relatively low, and high sediment accumulation rates resulted from turbidite deposition. Climatic oscillations, evidenced by changes in the nannoflora, characterized the latest Miocene. The periodic abundance of Bolboforma, primarily at Site 550 but also at Site 549, is associated with the destruction of foraminiferal tests caused by large-scale fluctuations in dissolution rates. The high percentages of windblown gymnosperm pollen types in the middle and upper Miocene sections indicate deposition far from shore (Brown and Downie, this vol.).

\section{Pliocene}

The Pliocene sequence of polarity reversals recognized at Site 548, although less well defined than the Pleistocene reversals, probably represents magnetic Anomalies $2 \mathrm{~A}$ to 3 (Fig. 4). At Site 550, where only the lower Pliocene was continuously cored, a series of short normalpolarity intervals represents at least some portion of the same sequence.

Lowermost Pliocene sediments (except at Site 549, where the Pliocene is absent because of an unconformity) contain nannofossil and planktonic foraminiferal assemblages that indicate-in terms of both diversity and species composition-warmer surface waters. The effects of dissolution were minimal in the earliest Pliocene, as evidenced by the excellent preservation at Site 550. Diverse benthic foraminiferal assemblages indicate that early Pliocene bottom waters at Site 548 were oxygen-enriched (Poag and Low, this vol.). An NADW-like water mass appears to have been well established.

The disappearance of warm-water species (keeled globorotaliids, Globigerinoides spp.), the increased abundance of cold-water forms (Globigerina bulloides, Globorotalia inflata), and reduced species diversity in planktonic foraminiferal faunas indicate climatic deterioration through the late Pliocene. The corresponding disappearance of discoasters also indicates cooling. According to Poag and Low (this vol.), a sea-level fall about $2.8 \mathrm{~m}$.y. ago corresponds to the establishment of an oxygen-minimum layer at Site 548. This event was 
marked by low overall benthic foraminiferal diversity, the abundance and high diversity of bolivinids, and the influx of terrigenous sediment. It corresponds rather closely to the onset of glaciation in the northern hemisphere some 2.8 to 2.5 m.y. ago (Berggren, 1972; Bizon and Müller, 1977; Backman, 1979). Some of the upper Pliocene terrigenous detritus at Leg 80 sites contains ice-rafted pebbles (Chennaux et al., this vol.). Shifting water masses and climatic fluctuations, evidenced by alternating floras and faunas, characterized the remainder of the late Pliocene. Bottom conditions stabilized in the latest Pliocene as sea level rose, and well-oxygenated waters returned (Poag et al., this vol.).

\section{THE QUATERNARY}

\section{Pleistocene}

Pleistocene sediments were cored at all four Leg 80 sites, but only at Sites 548 and 549 were significant thicknesses recovered; the mudline core was all that was available from Sites 550 and 551. Samples from Site 548 were strongly magnetized, and interpretation of the stable component was unequivocal. The upper Pleistocene section has a long normal-polarity interval down to 84 $\mathrm{m}$ sub-bottom. Below that are two normal-polarity intervals representing the Jaramillo and Olduvai events. The Pliocene/Pleistocene boundary, as identified using nannofossils and planktonic foraminifers, lies near the top of the Olduvai event. At Site 549 the Pleistocene sediments, which unconformably overlie the Miocene at $27 \mathrm{~m}$ sub-bottom, are of normal polarity. Refer to Figure 4 during the following discussion.

Both the planktonic foraminiferal fauna and the nannoflora indicate climatic fluctuations during the Pleistocene. Interglacial sediments have more diverse and floral assemblages, a higher percentage of temperate-water species, a rarity of benthic foraminiferal specimens, and only a minor amount of detrital material. Glacial sediments are characterized by sparser and less diverse planktonic faunal and floral assemblages, predominant coldwater species, benthic foraminiferal specimens (including displaced forms) in greater relative abundance, and detrital sediments. The nannofossil assemblages are rich in reworked Cretaceous and Tertiary specimens. Climatically controlled faunal, floral, and sedimentary alternations become more pronounced upward through the Pleistocene section.

Among Leg 80 sites, the Pleistocene section at Site 548 is the thickest $(101 \mathrm{~m})$, most complete, and best suited for detailed study. The Pliocene/Pleistocene boundary is difficult to define because of the absence of Discoaster in the upper Pliocene section. Pujos (this vol.) identifies the boundary within the Olduvai event, but Pujol and Duprat (this vol.) fix it at the top of that event. The short-lived stable environment established during the latest Pliocene began to deteriorate as sea level dropped across the Pliocene/Pleistocene boundary (Poag et al., this vol.). But regardless of its placement, there is no marked biological event associated with this boundary (Pujol and Duprat; Harland; both this volume).
Analyses of diverse microfossil groups at Site 548 all point to the same general pattern: fairly uniform conditions in the early to middle Pleistocene, followed by strong fluctuations in the late Pleistocene. Nannofossils (Pujos, this vol.), planktonic foraminifers (Pujol and Duprat, this vol.), carbonate content, detrital quartz content, benthic foraminifers (Caralp, this vol.), and dinoflagellates (Harland, this vol.) all reflect a similar and consistent pattern. The uniform lower to middle Pleistocene interval and the interglacial intervals in the upper Pleistocene are characterized by high carbonate content, rich and diverse planktonic foraminiferal and nannofossil assemblages, uniform dinoflagellate associations (indicating warm temperate conditions), and moderately diverse benthic foraminiferal faunas. Polar-front displacements, caused by ice-volume buildups during glacial episodes, resulted in high detrital quartz content, sparser and less diverse planktonic foraminiferal and nannofossil assemblages, less productive dinocyst associations (indicating cold temperate conditions), and a greater relative abundance of benthic foraminifers, including numerous displaced forms (from epibathyal and sublittoral environments). The abundance of benthic relative to planktonic foraminifers in glacial sediments is a result of preferential dissolution of the planktonic forms. The patterns described in the foregoing are superimposed upon more subtle trends involving general cooling and reduced sediment accumulation rates during the entire Pleistocene. The single most dramatic biologic "event" corresponds to the onset of climatic deterioration that characterized the late Pleistocene.

According to detailed planktonic foraminiferal zonations (Pujol and Duprat, this vol.), nannofossil studies (Pujos, this vol.), and magnetostratigraphy, the $27 \mathrm{~m}$ of Pleistocene sediments at Site 549 correlate with the uppermost 80 to $85 \mathrm{~m}$ of Pleistocene sediments at Site 548 . However, Pujol and Duprat note that a sudden lithologic change between Cores 2 and 3, Hole 549A probably indicates a sediment gap. Microfossil assemblages similar to those in the lower Pleistocene section at Site 548 are present at the bottom of Core 3 in Hole 549A (Harland; Caralp; both this vol.). The transition to marked faunal variations, characteristic of the upper Pleistocene at Site 548, occurs abruptly in the upper part of Core 3, Hole 549A. The upper part of the section at Site 549 contains cyclical variations similar to those in the uppermost unit at Site 548 (Pujol and Duprat, this vol.).

Faunal and floral alternations in the mudline cores of Sites 550 and 551 may correspond to the uppermost sections at Sites 548 and 549. But the abbreviated intervals available for study make such correlations conjectural.

\section{Surficial Sediments}

The Holocene(?) microfossil assemblages at all Leg 80 sites closely resemble those from interglacial episodes of the upper Pleistocene. Planktonic foraminiferal and nannofossil associations are moderately diverse, well preserved, and contain relatively high percentages of temperate-water species. Assemblages of planktonic foraminifers are quite similar to the subarctic and transitional assemblages of the present biocoenosis (Bé, 1977). 
Benthic foraminifers are well preserved but relatively scarce, and faunas show little evidence of downslope displacement.

\section{SUMMARY}

This section briefly summarizes events in chronological order for each individual site. Credit has been given to all contributors in the previous sections, so for brevity we omit such information here. Reference to Figure $1 \mathrm{~B}$ will be helpful during the following discussion.

\section{Site 548}

At Site 548 upper Campanian sediments immediately overlie a phosphatic calcareous hardground that encrusts the Hercynian basement. Upper Campanian through upper Maestrichtian foraminifer-nannofossil chalks were deposited in an epibathyal environment. A hiatus that spans the lowermost Paleocene interrupts this depositional sequence at the Cretaceous/Tertiary boundary.

The 1 to $2 \mathrm{~m}$ of foraminifer-nannofossil chalks representing the lower Paleocene accumulated in relatively cool epibathyal environments with well-oxygenated and relatively stable bottom conditions.

Above the unconformity that terminates the lower Paleocene sequence, upper Paleocene through lower Eocene marly nannofossil chalks were deposited in warmer, epibathyal waters. The bottom remained well oxygenated. A cooling trend began just before the episode represented by the overlying middle Eocene hiatus.

Upper middle Eocene through lower Oligocene foraminifer-nannofossil chalk accumulated in cool temperate waters at epibathyal to bathyal depths. Bottom conditions remained well oxygenated, but sediments accumulated in cooler water within slightly more offshore environments than those reflected in the lower Eocene.

An upper Oligocene through lower middle Miocene sedimentary sequence is separated from lower Oligocene chalk by an unconformity across which temperatures became slightly warmer. Fluctuating climatic conditions gradually gave way to warmer, more uniform conditions throughout the late Oligocene. Sediments accumulated in a somewhat shallower, but still epibathyal setting. Surface water temperatures dropped slightly across the Oligocene/Miocene boundary, and the resulting cool, well-oxygenated bottom conditions resembled those of the modern NADW mass. A major unconformity truncates the lower middle Miocene section.

A thick upper Miocene sequence of homogeneous nannofossil chalk interbedded with turbiditic silty mudstone is interrupted by an unconformity in the lower part of planktonic foraminiferal Zone N17. Upper Miocene sediments below this unconformity accumulated in cool, well-oxygenated waters at epibathyal depths.

The overlying uppermost Miocene through middle Pliocene sequence is lithologically similar, but deposition immediately above the unconformity took place in somewhat warmer waters. Because no significant change in depositional depth is indicated, a warmer water mass must have moved across the site, replacing the cooler NADW-like mass that was present earlier. Climatic fluctuations characterized the remainder of the Mio- cene, and oxygen-rich bottom waters were re-established by its end. Warm surface waters characterized the sarliest Pliocene; a cooler NADW-like mass continued to influence the bottom, however. Depths were still epibathyal to bathyal. A minor unconformity separates lower and upper Pliocene sediments.

The upper Pliocene through upper Pleistocene depositional sequence consists of alternating marly calcareous ooze and nannofossil ooze. The initiation of climatic fluctuations and the influx of terrigenous sediments marked the onset of Northern Hemisphere glaciation. Mild fluctuations and relatively long periods of uniform climate characterized the early Pleistocene, and were followed by rapid climatic fluctuations in the late Pleistocene. Qualitative changes in benthic foraminiferal assemblages indicate that the top of an NADW-like mass fluctuated with the climate, moving back and forth across Site 548 several times. A minor hiatus occurs in the upper Pleistocene. Subsequent sediments accumulated in fluctuating conditions until the modern MOW mass became established.

Subsidence at Site 548 has been gradual; depths have been epibathyal to bathyal since deposition was initiated in the late Campanian. Some but not all of the hiatal intervals correspond to major drops in sea level (Vail and Hardenbol, 1979). But changing oceanographic conditions were associated with nearly all unconformities, indicating the movement of distinct water masses across the site. Changing water masses and patterns of bottomwater circulation, some linked to eustatic sea-level change but others related to different causes, controlled the erosional/depositional history at this site.

\section{Site 549}

Site 549 contains the only syn-rift sedimentary sequence cored during Leg 80 . A 290-m sequence of upper Hauterivian(?) and lower through basal upper Barremian sediments unconformably overlies the Hercynian basement. Each of the three lithologic units comprising the Barremian contains a distinctive nannofloral and foraminiferal assemblage. The succession of assemblages, along with changes in organic matter and pollen types, indicates a warm climate and progressive change from shallow, brackish water to inner-shelf to outer-shelf or upper-slope environments.

A 9.7-m red, sandy dolosparite with a complex history of marine deposition, brackish- or fresh-water cementation, and subaerial diagenesis may represent a remnant of Aptian deposition at Site 549.

Above the "breakup" unconformity (hiatus of about 9 m.y.), a thick (190-m) post-rift calcareous siltstone sequence represents the Albian. These sediments accumulated in a middle to lower bathyal environment during a period of mild climatic fluctuations.

Lying unconformably above the Albian is a sequence of Cenomanian nannofossil chalk that was probably deposited in a bathyal environment. Extensive fragmentation and dissolution of microfossils were caused by diagenesis.

Above the unconformity that truncates the Cenomanian is a condensed but continuous Turonian through 
middle Maestrichtian section. A high sea-level stand may have trapped sediment on the adjacent continental shelf throughout most of this interval. The Turonian is represented by nannofossil chalks and black shales rich in organic matter. The widespread anoxic episode that correlates with deposition of the shales was anomalous within the well-oxygenated environments that characterized the remainder of the Late Cretaceous. Poor preservation hinders detailed biostratigraphic and environmental interpretations of the Santonian/Coniacian section, but better-preserved assemblages in the Campanian and lower Maestrichtian suggest deposition in a bathyal environment.

A thin upper Maestrichtian section of nannofossil chalk is bounded both above and below by unconformities. Well-preserved microfossil assemblages indicate deposition in an environment similar to that of the early Maestrichtian.

Above the basal Paleocene unconformity, lower Paleocene nannofossil chalks accumulated in relatively cool, epibathyal to bathyal waters.

Lying unconformably above is a thick sequence of upper Paleocene through Oligocene marly nannofossil chalk and nannofossil chalk. Most of this section (206 $\mathrm{m})$ lies within the Eocene. Two unconformities, both of very limited duration, have been tentatively identified within the Eocene; otherwise, deposition appears to have been continuous. Late Paleocene surface waters were warmer than those of the early Paleocene. Relatively warm surface waters continued into the early Eocene; middle Eocene deposits accumulated in cool temperate waters at bathyal depths. Gradual cooling of surface waters continued during the late Eocene. Major faunal and floral changes were gradual, and there is no evidence of a traumatic terminal Eocene event. In the early Oligocene, a rapid cooling event, marked by benthic faunal changes, signalled the introduction of colder, more vigorously circulating bottom water from a northern source. A coincident but less pronounced cooling of surface waters took place. A middle Oligocene unconformity interrupts the sequence.

A condensed upper Oligocene sequence is bounded above and below by unconformities. The homogeneous nannofossil chalks of this section also accumulated in a bathyal environment, but water temperatures were warmer that those of the early Oligocene.

Two biostratigraphically distinct depositional sequences, both nannofossil chalk and both bounded by unconformities, comprise the condensed Miocene section. Indications of climatic fluctuations characterize these sediments. The hiatal interval that followed Miocene deposition accounts for the entire Pliocene and the lower Pleistocene.

The condensed Quaternary section of marly calcareous nannofossil ooze and foraminiferal ooze accumulated in a bathyal environment that remained largely within an NADW-like mass. This site was evidently far enough down the continental slope so that bottom conditions were not affected by Pleistocene climatic fluctuations. Planktonic microfossil assemblages do, however, reflect some of the alternations noted at Site 548 .
The sedimentary and paleontological record at Site 549 includes the initial rifting episode in this part of the North Atlantic. As at Site 548, not all of the subsequent hiatal intervals correspond to low sea-level stands on published curves. Certainly, bottom-circulation patterns along this evolving continental margin were of prime importance in determining depositional history.

\section{Site $\mathbf{5 5 0}$}

At Site 550 the basalt flows and pillows of the basement are directly overlain by Albian carbonates (alternating bioturbated and laminated calcareous mudstones) deposited in a lower bathyal to abyssal environment. Lying conformably above is a lower Cenomanian section of similar lithology, deposited in generally well oxygenated conditions. However, several layers of laminated black shale indicate periodic anoxic conditions, and discrete horizons of dissolution reflect irregular intensities of diagenetic alteration. An unconformity truncates this sequence.

Dark clays interbedded with white chalks grade upward into dark claystone in the overlying Santonian/Coniacian section. Nannofossils are absent in the lower part, probably owing to deposition below the carbonate compensation depth. Foraminiferal assemblages were used to interpret the contact with underlying Cenomanian deposits.

Above the Santonian/Coniacian lies a condensed sequence of Campanian through lowermost Paleocene nannofossil and marly nannofossil chalks interbedded with calcareous mudflows and turbidites. The Campanian part of the sequence was probably deposited below the carbonate compensation depth. Consequently, the nature of the contact with underlying Santonian/Coniacian claystones is difficult to determine. It may be unconformable, but if so, the duration of the hiatus is unknown. The continuous, relatively thick, largely turbiditic Maestrichtian sequence was deposited in an abyssal environment, as indicated by well-preserved microfossil assemblages. The Cretaceous/Tertiary boundary at this site appears to be conformable.

A 20-m section of lower Paleocene marly nannofossil chalk is bounded above by an unconformity. Calcareous microfossils from several horizons have been subjected to severe dissolution.

Except for indications of an episode of dissolution during the late Paleocene, preservation is much better in the overlying upper Paleocene through lower Eocene sequence, in which marly nannofossil chalk grades upward into siliceous nannofossil chalk and mudstone. Diverse planktonic microfossil assemblages (calcareous and siliceous) indicate relatively warm surface waters.

Microfossil assemblages in the uppermost Eocene section-which is condensed and incomplete because of unconformities above and below-indicate the establishment of cold-water circulation. The overlying upper Oligocene is also condensed, incomplete, and characterized by extensive dissolution. It is, in turn, unconformably overlain by a thick lower and middle Miocene sequence of marly nannofossil chalks and interbedded turbidites. Bolboforma first becomes conspicuous in the 
lower Miocene, indicating the continued influence of cold temperate surface waters. Cold-water conditions persisted through the middle Miocene. The upper Miocene hiatus, also recognized at other Leg 80 sites, was probably caused by vigorous bottom-water circulation.

Uppermost Miocene through middle Pliocene marly nannofossil chalks lie above the unconformity. The late Miocene was a time of climatic fluctuations, whereas planktonic microfossils dating from the early Pliocene indicate warmer surface waters. The upper part of the Pliocene and most of the Pleistocene were not cored.

Latest Pleistocene climatic fluctuations are evident in the mudline core. At least three distinct climatic episodes (one glacial between two interglacial) can be recognized.

Many of the same hiatal intervals recognized at Sites 548 and 549 are recorded at Site 550. Timing of these events among the sites was not exactly synchronous, but Paleocene, middle Eocene, middle Oligocene, and late middle Miocene episodes of erosion or nondeposition were widespread. Site 550 has been situated at abyssal depths since the initiation of marine deposition in the late Albian. Fluctuations in the carbonate compensation depth and in depositional/erosional history reflect changes in water-mass characteristics and in bottom-water circulation.

\section{Site 551}

A Cenomanian through lower Turonian sedimentary sequence lies on basalt flows and pillows at Site 551. Cenomanian nannofossil chalk and siliceous mudstone are characterized by extensive fragmentation and dissolution of both carbonate and siliceous microfossils. Black organic shales of the Turonian record an anoxic event also noted at Site 549. A major unconformity (hiatus of about $20 \mathrm{~m} . \mathrm{y}$.) truncates this sequence.

The overlying upper Campanian through middle Maestrichtian is composed of mottled calcareous ooze and chalk. Well-preserved microfossil assemblages indicate deposition in a bathyal environment.

A very thin $(2-\mathrm{cm})$ layer of upper Paleocene sediments rests unconformably on the Maestrichtian. Above lies a condensed lower to lower middle Eocene sequence of calcareous mudstone, but it was not continuously cored. Detailed information on younger deposits is not available, owing to lack of sampling.

\section{Composite}

A composite section based on all four Leg 80 sites produces a nearly complete stratigraphic record of both syn-rift and post-rift sequences in the vicinity of Goban Spur. Portions of the section that are missing or condensed at one site are often well represented at another site. There are, however, several regional unconformities that mark widespread episodes of erosion or nondeposition.

The oldest deposits above basement rocks are Barremian. Lower Barremian mudstones accumulated in a shallow, marginal-marine, brackish-water environment. Grainstones from the middle part of this thick syn-rift sequence accumulated in an inner-shelf environment with more normal marine influence. Upper Barremian calcareous sandstones were deposited in an outer-shelf, possibly upper-slope, environment.

Definite Aptian sediments were not encountered at any of the Leg 80 sites, but $9.7 \mathrm{~m}$ of sandy dolosparite at Site 549 may be a remnant of Aptian strata. The oldest post-basement sediments at other sites are considerably younger. Apparent irregularities in the thickness, distribution, and completeness of Cretaceous sequences at Leg 80 sites are caused by variations in their position: (1) along the margin of an incipient oceanic basin, (2) within their respective half-grabens. Sedimentary sequences are thicker and more complete near the axes of these small depositional basins.

Post-rift Albian mudstones and siltstones offer the first evidence for a developing deep-water seaway in this region. Site 549 had subsided to bathyal depths during their deposition, and Site 550 was at lower bathyal to abyssal depths.

Cenomanian middle to lower bathyal chalks and mudstones (Sites 549 and 551) are characterized by extensive dissolution throughout. Variably preserved abyssal deposits (Site 550) record alternate oxic and anoxic conditions.

Turonian sediments (Sites 549 and 551) consist in part of a condensed black shale sequence. The anoxic conditions associated with these bathyal deposits were anomalous but widespread within the well-oxygenated conditions that characterized the remainder of the Late Cretaceous.

Poor preservation characterizes assemblages from Santonian/Coniacian chalks and claystones. Dissolution was extensive at bathyal (Site 549) and abyssal (Site 550) depths.

Although lower Campanian chalks and turbidites at abyssal depths (Site 550) were subjected to dissolution, Campanian chalks at all other sites contain well-preserved microfossil assemblages indicating deposition in bathyal environments. The latest Campanian and Maestrichtian interval marked the first time that marine sediments were uniformly and widely distributed across the entire Goban Spur region. Growth of the Atlantic basin, coupled with infilling of the half-grabens, had evidently served to stabilize environmental conditions. Gradual subsidence of the margin and adjacent crust since Albian time produced the water depths of the Holocene (Site 548, epibathyal; Site 549, bathyal; Site 550, abyssal; Site 551 , lower bathyal).

Because changes in depth were gradual during the Tertiary, climatic changes became more conspicuous. Lower Paleocene chalk accumulated in cool, well-oxygenated bottom water. A widespread middle Paleocene hiatus interrupts the sequence at all sites. Upper Paleocene marly chalk, mudstone, and turbidites were deposited in warmer waters. Bottom conditions remained well oxygenated.

Relatively warm surface-water conditions continued into the early Eocene, but a major cooling trend began in the middle Eocene. Except at Site 549, the middle Eocene section is partially absent because of an unconformity, and cool temperate assemblages appear abruptly above the unconformable surface. The more complete 
section at Site 549 documents gradual cooling of surface and bottom waters throughout the middle and particularly during the late Eocene.

The cooling trend intensified during the early Oligocene. Cold, vigorously circulating bottom waters from a northern source were introduced into the region. A widespread middle Oligocene hiatus, probably associated with changing circulation patterns, separates these coldwater marly chalks from upper Oligocene chalks deposited in warmer, mildly oscillating conditions. Evidence of these events was largely destroyed by dissolution at Site 550 .

Evidence of climatic fluctuations characterizes Miocene chalks and turbiditic mudstones. Early Miocene bottom waters remained well oxygenated but became cooler, resembling the modern NADW mass. A widespread unconformity, most likely caused by vigorous bottom-water circulation, marks the middle Miocene. Warmer waters of the late Miocene corresponded to the establishment of an oxygen-minimum zone at Site 548 (similar to the modern MOW mass). Re-establishment of the cooler NADW-like mass followed rather quickly.

Surface waters warmed considerably during the early Pliocene, but a cool, NADW-like mass continued to influence the bottom. Upper Pliocene sediments and assemblages indicate mildly fluctuating, generally cooler climatic conditions. The initiation of glacial activity was marked by the influx of terrigenous sediments. An oxygen-minimum zone existed at Site 548 just before the initial glacial influence; the MOW-like mass was quickly replaced by a cooler, NADW-like mass.

Relatively mild and gradual climatic fluctuations continued into the early Pleistocene. The upper Pleistocene section is marked by the onset of rapid, more severe fluctuations. The upper boundary of an NADW-like mass repeatedly moved back and forth across Site 548; deeper-water sites remained under the influence of an NADW-like mass.

Surficial sediments and assemblages resemble those of interglacial Pleistocene deposits. Site 548 is presently influenced by the MOW mass; other sites are covered by the NADW mass.

\section{ACKNOWLEDGMENTS}

We thank Robert Thunell and Detmar Schnitker for their critical reading of the manuscript.

\section{REFERENCES}

Backman, J., 1979. Pliocene biostratigraphy of DSDP Sites 111 and 116 from the North Atlantic Ocean and the age of Northern Hemisphere glaciation. Stockholm Contr. Geol., 32:115-137.

Bartenstein, H., 1978. Paleontological zonation; parallelisation of the Lower Cretaceous stages in northwest Germany with index ammonites and index microfossils. Erdoel Kohle, 31:65-67.

Bé, A. W. H., 1977. An ecological, zoogeographic and taxonomic review of Recent planktonic foraminifera. In Ramsay, A. T. S. (Ed.), Oceanic Micropaleontology: London (Academic Press), pp. 1-100.

Berggren, W. A., 1972. Cenozoic biostratigraphy and paleobiogeography of the North Atlantic. In Laughton, A. S., Berggren, W. A., et al., Init. Repts. DSDP, 12: Washington (U.S. Govt. Printing Office), 965-1001.

Berggren, W. A., Kent, D. V., and Flynn, J. J., in press. Paleogene geochronology and chronostratigraphy. In Snelling N. J. (Ed.), Geo- chronology and the Geological Record. Spec. Pap. Geol. Soc. London.

Berggren, W. A., and Van Couvering, J. A., 1974. The late Neogenebiostratigraphy, geochronology and paleoclimatology of the last 15 million years in marine and continental sequences. Palaeogeogr., Palaeoclimatol., Palaeoecol., 16:1-216.

Bettensteadt, F., 1952. Stratigraphisch wichtige Foraminiferen-Arten aus dem Barrême vorwiegend Nordwest-Deutschlands. Senckenbergiana, 33:263-295.

Bizon, G., and Müller, C., 1977. Remarks on some biostratigraphic problems in the Mediterranean Neogene. Internat. Symp. Structural History Mediterranean Basins: Paris (Technip), pp. 381-390.

Blow, W. H., 1969. Late Middle Eocene to Recent planktonic foraminiferal biostratigraphy. In Brönnimann, P., and Renz, H. H. (Eds.), Proc. First Internat. Conf. Planktonic Microfossils (Vol. 1): Leiden (Brill), pp. 199-422.

Bukry, D., and Bramlette, M. N., 1970. Coccolith age determinations, Leg 3, Deep Sea Drilling Project. In Maxwell, A. E., Von Herzen, R., et al., Init. Repts. DSDP, 3: Washington (U.S. Govt. Printing Office), 589-611.

Cepek, P., and Hay, W. W., 1969. Calcareous nannoplankton and biostratigraphic subdivision of the Upper Cretaceous. Trans. Gulf Coast Assoc. Geol. Soc., 19:323-336.

Corliss, B. H., 1979. Response of deep-sea benthonic foraminifera to development of the psychrosphere near the Eocene/Oligocene boundary. Nature, 282:63-65.

1981. Deep-sea benthonic foraminiferal faunal turnover near the Eocene/Oligocene boundary. Mar. Micropaleontol., 6: 367-384.

Costa, L. I., and Downie, C., 1979. Cenozoic dinocyst stratigraphy of Sites 403 to 406 (Rockall Plateau), IPOD Leg 48. In Montadert, L., Roberts, D. G., et al., Init. Repts. DSDP, 48: Washington (U.S. Govt. Printing Office), 513-530.

de Graciansky, P. C., Brosse, E., Deroo, G., Herbin, J.P., Montadert, L., et al., 1982. Les formations d'âge Crétacé de l'Atlantique Nord et leur matierè organique: Paléogéographie et milieux de dépôt. Rev. Inst. Fr. Pet., 37:105-166.

Hailwood, E. A., Bock, W., Costa L., Dupeuble, P. A., Müller, C., et al., 1979. Chronology and biostratigraphy of northeast Atlantic sediments, DSDP Leg 48. In Montadert, L., Roberts, D. G., et al., Init. Repts. DSDP, 48: Washington (U.S. Govt. Printing Office), 305-339.

Knox, R. W. O'B., and Morton, A. C., in press. Stratigraphical distribution of early Paleogene pyroclastic deposits in the North Sea Basin. Proc. Yorks. Geol. Soc.

Martini, E., 1971. Standard Tertiary and Quaternary calcareous nannoplankton zonation. In Farinacci, A. (Ed.), Proc. Second Annual Planktonic Conf.: Rome (Tecnoscienza), pp. 739-785. 1976. Cretaceous to Recent calcareous nannoplankton from the central Pacific Ocean (DSDP Leg 33). In Schlanger, S. O., Jackson, E. D., et al., Init. Repts. DSDP, 33: Washington (U.S. Govt. Printing Office), 383-423.

Poore, R. Z., 1979. Oligocene through Quaternary planktonic foraminiferal biostratigraphy of the North Atlantic: DSDP Leg 49. In Luyendyk, B., Cann, J. R., et al., Init. Repts. DSDP, 49: Washington (U.S. Govt. Printing Office), 447-476.

Shackleton, N. J., and Kennett, J. P., 1975. Paleotemperature history of the Cenozoic and the initiation of Antarctic glaciation: Oxygen and carbon isotope analyses in Deep Sea Drilling Project Sites 277, 279, and 281. In Kennett, J. P., Houtz, R. E., et al., Init. Repts. DSDP, 29: Washington (U.S. Govt. Printing Office), 743-755.

Sigal, J., 1977. Essai de zonation du Crétacé méditerranéen à l'aide des foraminifères planctoniques. Geol. Mediterraneenne, 4:99-108.

Stainforth, R. M., Lamb, J. L., Luterbacher, H., Beard, J. H., and Jeffords, R. M., 1975. Cenozoic planktonic foraminiferal zonation and characteristics of index forms. Univ. Kan. Paleontol. Contr., 62:1-425.

Thierstein, H. R., 1973. Lower Cretaceous calcareous nannoplankton biostratigraphy. Abh. Geol. B.-A. (Wien) 29:1-52.

1976. Mesozoic calcareous nannoplankton biostratigraphy of marine sediments. Mar. Micropaleontol., 1:325-362.

Tjalsma, R. C., and Lohmann, G. P., 1983. Paleocene-Eocene bathyal and abyssal benthic foraminifera from the Atlantic Ocean. Micropaleontology Spec. Publ. 4. 
S. W. SNYDER ET AL.

Vail, P. R., and Hardenbol, J., 1979. Sea-level change during the Tertiary. Oceanus, 22:71-79.

van Hinte, J. E., 1976. A Cretaceous time scale. Am. Assoc. Petrol. Geol. Bull., 60:498-516.

von Daniels, C. H., and Spiegler, D., 1974. Bolboforma n. gen. (Protozoa?)-eine neue stratigraphische wichtige Gattung aus dem Oligozän/Miozän Nordwestdeutschlands. Z. Palaontol., 48:57-76.
Woodruff, F., Savin, S. M., and Douglas, R. G., 1981. Miocene stable isotope record: a detailed deep Pacific Ocean study and its paleoclimatic implications. Science, 212:665-668.

Date of Initial Receipt: August 2, 1983

Date of Acceptance: November 17, 1983 